\title{
The dynamic response of the rand real exchange rate to fundamental shocks
}

\author{
Mehmet Balcilar \\ Department of Economics, Eastern Mediterranean University, Famagusta, \\ Northern Cyprus and \\ Department of Economics, University of Pretoria, Pretoria, South Africa, and \\ Rangan Gupta and Charl Jooste \\ Department of Economics, University of Pretoria, Pretoria, South Africa
}

\begin{abstract}
Purpose - The authors analyse the relationship between the South African real exchange rate and economic fundamentals - demand, supply and nominal shocks. The paper aims to discuss these issues. Design/methodology/approach - The authors use a time-varying parameter VAR to study the coherence, conditional volatility and impulse responses of the exchange rate over specific periods and policy regimes. The model is identified using sign-restrictions that allow for some neutrality of impulse responses over contemporaneous and long horizons.

Findings - The results suggest that the importance of fundamental shocks on the exchange rate is time dependent. Hence there is a loss in information when using standard linear models that average out effects over time. The response of the exchange rate to demand and supply shocks have weakened over the 1994-2010 period.

Research limitations/implications - The period following financial crisis has strengthened the relationship between supply and demand shocks to the exchange rate, but has weakened the relationship between interest rate shocks and the exchange rate response.

Practical implications - This paper provides deeper insight as to how the exchange rate responds to fundamental shocks. This should help monetary policy understand the consequences of interest rate decisions on the exchange rate and the indirect effect of inflation on the exchange rate.

Originality/value - This application is new to the South African literature. The authors propose that the use of interest rates is limited in affecting the value of the rand exchange rate over particular periods. Isolating fundamental shocks to exchange rates over time helps policy makers make clearer and more informed decisions.
\end{abstract}

Keywords Exchange rates, Fundamentals, Sign-restricted TVP-VAR

Paper type Research paper

\section{Introduction}

The exchange rate is an important macroeconomic variable that reflects South Africa's internal and external balances. It plays a crucial role for inflation targeting countries that functions as a shock absorber in bringing the economy back to equilibrium[1]. We analyse the dynamic relationship between the real rand-dollar exchange rate and with fundamental shocks. We argue that the response of the exchange rate to prices and output has weakened since inflation targeting, but has remained relatively stable since 2005 . Furthermore, exchange rate volatility relative to price and output volatility has also increased over time suggesting that news and non-fundamental shocks have become important drivers of the rand exchange rate. An important result shows that the impact of interest rate shocks on the exchange rate has weakened since the 2008/2009 financial crisis. 
This has implications for standard DSGE models used by central banks to model policy scenarios as well as for policy makers regarding currency intervention.

The policy implications are clear: non-interventionist policy requires that the exchange rate be left to float freely along with changes to structural shocks - on the assumption that structural shocks are the core determinants of the exchange rate. This idea can be contested when exchange rate volatility is not a function of structural shocks - a decoupling effect. Speculative attacks, liquidity shocks such as the US and EU quantitative easing and carry trade cause distortions that could lead to unwanted exchange rate outcomes. Whether the South African government should or could correct for these distortions remains an open debate. In our view, it is important to test whether the exchange rate has moved out of step with structural shocks.

We use a time-varying sign-restricted VAR as in Mumtaz and Sunder-Plassmann (2013) to shed light on changes to the exchange rate to shocks in growth, interest and price differentials to the USA - thus controlling for purchasing power parity (PPP), uncovered interest parity (UIP) and Balassa-Samuelson (BS) effects (these underlie the heart of equilibrium exchange rate studies - see MacDonald and Ricci, 2004; Chong et al., 2010). However, this is not a model of equilibrium exchange rates. We mainly focus on the short-run dynamics of this model where fundamental shocks are identified from theory. In essence, shifts to the exchange rate over time due to fundamental shocks might imply a time-varying cointegrating vector - something perhaps to be tested in a follow-up research project. Hence, our approach is consistent with Mumtaz and Sunder-Plassmann (2013) that estimates the simultaneous short-run relationship between the exchange rate and fundamental shocks.

As pointed out by Mumtaz and Sunder-Plassmann (2013) constant parameter VARs are not able to capture important changes to the economy and will average out effects that might be period specific. Such effects could include advances in technology, global economic crises and simple shifts in fundamentals. Each specific point in time could characterise a specific regime.

We contribute to the existing literature by studying how the South African Rand has reacted to fundamental shocks, and specifically whether there are signs of co-movement or decoupling with fundamental shocks over time. We motivate this study on two grounds: First, if exchange rates are decoupled from fundamental shocks, then further research on standard models of equilibrium exchange rate are required to accurately trace shocks, and second, it is important to factor in the time and regime dependence of the exchange rate when making monetary policy decisions.

\section{Literature review}

This study is not the first to analyse the behaviour of the rand to structural shocks, but is the first, as far as we know, that tries to understand it from a time-varying perspective. One further justification for using a time-varying parameter VAR (TVP-VAR) is that behavioural exchange rate models (as is often the case in trying to identify equilibrium exchange rates) are poor forecast performers over the short-run; something that Meese and Rogoff (1983) show: they fail to out-predict a random walk at. This also seems to be the case for South Africa (see Égert, 2012; Fattouh et al., 2008).

Behavioural exchange rate models usually assume a standard set of theoretical relationships. We will briefly mention them here since they are part of what we mean by fundamentals and illustrate them with the help of a simple theoretical model in the next section.

If a fundamental exchange rate exists, then any shocks will only cause temporary deviations from some structural level. The variables that often characterise this 
fundamental relationship are productivity differentials, interest rate differentials and price differentials. While equilibrium is usually established through some empirical approach that finds a cointegrating vector. If there is no cointegration, then an exchange rate does not have a fundamental relationship with these variables. However, as noted previously, our focus is on identifying fundamental shocks and analysing the short-run dynamic response of the exchange rate.

It is assumed that the expected exchange rate will appreciate under positive interest rate differentials (UIP). The PPP condition refers to the convergence of prices of similar perfectly traded goods across borders (Chong et al., 2010). Empirical research finds that PPP generally holds in the long-run for South Africa (see Gupta et al., 2009; Lacerde et al., 2010; Sichei et al., 2005; Raputsoane and Todani, 2008; De Bruyn et al., 2012).

The BS hypothesis offers an alternative explanation for why deviations from PPP occur over the long-term and is primarily ascribed to productivity differentials (Froot and Rogoff, 1994; Rogoff, 1996). It is expected that positive productivity differentials will appreciate the exchange rate to align productivity between the traded and nontraded sectors. The evidence regarding BS is mixed at best. In contrast to BS, Benigno and Thoenissen (2003) show that productivity gains can lead to real depreciations. An increase in productivity implies an increase in output at any price. Consequently the relative price of home produced goods must fall, implying a fall in the terms of trade and hence an exchange rate depreciation. However, domestic productivity shocks in the traded sector leads to an appreciation (only if domestic traded goods firms have no home and foreign pricing power) - which conforms to the BS hypothesis.

Other variables are often included in the standard fundamental model and have significant explanatory power. These include capital-flows, tariffs, gold prices and fiscal policy (see Aron et al., 1997; MacDonald and Ricci, 2004 and Faulkner and Makrelov, 2008). This suggests other factors, other than just the standard list of variables, move the rand away or towards some equilibrium value. Du Plessis (2005) raises an important issue that some of the papers fail to report on - the implications of weak exogeneity of the exchange rate. A weak exogenous rand could invalidate obtaining a model of the rand, and hence questions the existence of an equilibrium exchange rate.

Table I summarises some of these papers for South Africa, their methods and conclusions.

Using Bayesian methods allows us to depart from standard linear and normality assumptions and helps us deal with regime shifts that could influence both the sign and size of coefficients.

\section{A simple model of the exchange rate}

Clarida and Gali (2004) serve as background to our empirical model. All variables, except interest rates, are in logs and are specified as deviations of the home country from foreign country. In the short-run prices adjust sluggishly to demand, supply and nominal shocks. The long-run characterises the equilibrium when prices adjust fully to all shocks. The model consists of an IS equation, a price-setting equation, an interest parity equation and money equation:

$$
\begin{gathered}
y_{t}^{d}=d+\tau q_{t}-\sigma\left(i_{t}-E_{t}\left(p_{t+1}-p_{t}\right)\right) \\
p_{t}=(1-\theta) E_{t-1} p_{t}^{e}+\theta p_{t}^{e}
\end{gathered}
$$


Table I. A summary ofexchange rate models for South Africa

\begin{tabular}{|c|c|c|c|}
\hline Authors & Objective & Conclusion & Method \\
\hline $\begin{array}{l}\text { MacDonald and } \\
\text { Ricci (2004) }\end{array}$ & $q$ linked to UIP, BS, & $\begin{array}{l}\text { Is cointegrated with UIP and } \\
\text { BS. } 2-2.5 \text { years to revert back } \\
\text { to equilibrium }\end{array}$ & VECM \\
\hline De Jager (2012) & $q$ linked to UIP and BS & $\begin{array}{l}\text { Is cointegrated with UIP and } \\
\text { BS. } 1 \text { year to revert back } \\
\text { to equilibrium }\end{array}$ & VECM \\
\hline Aron et al. (1997) & $\begin{array}{l}q \text { linked to tariffs, terms of } \\
\text { trade, price of gold, capital } \\
\text { flows, reserves and government } \\
\text { consumption }\end{array}$ & $\begin{array}{l}\text { Is cointegrated. } 7 \text { quarters to } \\
\text { return to equilibrium }\end{array}$ & $\begin{array}{l}\text { Single equation } \\
\text { cointegration } \\
\text { regression }\end{array}$ \\
\hline Du Plessis (2005) & $\begin{array}{l}\text { Critique on MacDonald and } \\
\text { Ricci (2004) model }\end{array}$ & $\begin{array}{l}\text { Suggests that MacDonald and } \\
\text { Ricci (2004) did not identify an } \\
\text { exchange rate model due to } \\
\text { weak exogeneity in the } \\
\text { exchange rate is }\end{array}$ & VECM \\
\hline $\begin{array}{l}\text { MacDonald and } \\
\text { Ricci (2004) }\end{array}$ & $\begin{array}{l}\text { Extend previous analysis based } \\
\text { on Du Plessis (2005) critique }\end{array}$ & $\begin{array}{l}\text { Weak exogeneity is overcome } \\
\text { by extending historical data }\end{array}$ & VECM \\
\hline Sichei et al. (2005) & $\begin{array}{l}\text { Monetary approach to } \\
\text { equilibrium exchange rate } \\
\text { model }\end{array}$ & $\begin{array}{l}\text { Is cointegrated with UIP, BS } \\
\text { and PPP. }\end{array}$ & VECM \\
\hline $\begin{array}{l}\text { Raputsoane and } \\
\text { Todani (2008) }\end{array}$ & $\begin{array}{l}\text { Monetary approach to } \\
\text { equilibrium exchange rate } \\
\text { model }\end{array}$ & $\begin{array}{l}\text { Is cointegrated with UIP, BS and } \\
\text { PPP. However, the sign on BS } \\
\text { implies currency depreciation }\end{array}$ & VECM \\
\hline $\begin{array}{l}\text { De Bruyn et al. } \\
\text { (2012) }\end{array}$ & $\begin{array}{l}\text { Monetary approach to } \\
\text { equilibrium exchange rate } \\
\text { model }\end{array}$ & Is cointegrated with BS & VECM \\
\hline $\begin{array}{l}\text { Fattouh et al. } \\
\text { (2008) }\end{array}$ & $q$ linked to UIP and PPP & $\begin{array}{l}\text { Is cointegrated with PPP } \\
\text { and UIP }\end{array}$ & MS-VECM \\
\hline $\begin{array}{l}\text { Lacerde } \text { et al. } \\
\text { (2010) }\end{array}$ & $q$ linked to UIP and PPP & $\begin{array}{l}\text { Is cointegrated with PPP } \\
\text { and UIP }\end{array}$ & MS-VECM \\
\hline $\begin{array}{l}\text { Faulkner and } \\
\text { Makrelov (2008) }\end{array}$ & Manufacturing $q$ linked to BS & Is cointegrated with BS & $\begin{array}{l}\text { Single equation } \\
\text { cointegration }\end{array}$ \\
\hline
\end{tabular}

Note: $q$ refers to the exchange rate

$$
\begin{aligned}
& i_{t}=E_{t}\left(s_{t+1}-s_{t}\right) \\
& m_{t}^{s}-p_{t}=y_{t}-\gamma i_{t}
\end{aligned}
$$

$y_{t}^{d}$ is the relative output, $q_{t}=\left(s_{t}-p_{t}\right)$, the real exchange rate, $s_{t}$, the nominal exchange rate, $p_{t}$, the relative prices, $i_{t}$, the interest rate differential, $m_{t}^{s}$, the money supply. $d$ is a demand shock. The IS Equation (1) shows that relative output is positive in a demand shock, increases with a real exchange rate depreciation and decreases when relative interest rates increase. Equation (2) shows that prices are a weighted average between the expected market clearing price and the price that would actually clear output markets. Equation (3) is the standard UIP equation, while Equation (4) links money to the real economy.

Three stochastic shocks are introduced: relative supply, demand and a nominal shock $\left(y_{t}^{s}, d_{t}, m_{t}\right)$. They are modelled as random walks, while the demand shock contains both a temporary and permanent shock:

$$
y_{t}^{s}=y_{t-1}^{s}+\varepsilon_{t}^{s}
$$




$$
\begin{gathered}
d_{t}=d_{t-1}+\varepsilon_{t}^{d}-\rho \varepsilon_{t-1}^{d} \\
m_{t}=m_{t-1}+\varepsilon_{t}^{m}
\end{gathered}
$$

The model's long-run solution is obtained by plugging (5)-(7) into (1) and solving for $q_{t}$ :

$$
q_{t}=\frac{y_{t}^{s}-d_{t}}{\tau}+\frac{\sigma \rho \varepsilon_{t}^{d}}{\tau(\tau+\sigma)}
$$

Using (4), (7) and (8) we can write out the equation for relative prices:

$$
p_{t}^{e}=m_{t}-y_{t}^{s}+\frac{\gamma}{1+\gamma} \frac{\rho \varepsilon_{t}^{d}}{\tau(\tau+\sigma)}
$$

Using our assumption of sluggish prices substitute (9) into (2):

$$
p_{t}=p_{t}^{e}-(1-\theta)\left(\varepsilon_{t}^{m}-\varepsilon_{t}^{s}+\left(\frac{\gamma}{1+\gamma} \frac{\rho}{(\tau+\sigma)}\right) \varepsilon_{t}^{d}\right)
$$

The real exchange rate can then be represented by substituting (1) and (3) into (4) and using (10):

$$
q_{t}=q_{t}^{e}+\frac{1+\gamma}{\sigma+\tau+\gamma}\left(\varepsilon_{t}^{m}-\varepsilon_{t}^{s}+\left(\frac{\gamma}{1+\gamma} \frac{\rho}{(\tau+\sigma)}\right) \varepsilon_{t}^{d}\right)
$$

From Equation (11) - a demand shock appreciates the exchange rate. This depends on the parameter size that governs the effects of the exchange rate and interest on output and money supply as well as the persistence of the demand shock. The empirical model is used to analyse both the sign and size of the respective fundamental shocks.

\section{Methodology}

We use quarterly data from 1981Q1 to 2013Q4. The data are sourced from the South African Reserve Bank (SARB) and the International Monetary Fund. We use the difference between South Africa's and the USA's short-term treasury bill for our interest rate differential (deflated using consumer price inflation), we use the difference between South Africa's and the USA's consumer price inflation for price differentials, and for growth differentials we use the difference between South Africa's and the USA's real GDP seasonally adjusted and annualised data[2].

Our methodology, and hence notation, follows Mumtaz and Sunder-Plassmann (2013). The TVP-VAR builds on Primiceri (2005). We use the same approach as in Mumtaz and Sunder-Plassmann (2013) in identifying our shocks. Primiceri (2005) used a Cholesky decomposition, while Mumtaz and Sunder-Plassmann (2013) use sign-restrictions. A lag length of two is chosen based on the Bayesian Information Criterion. Three shocks are identified - demand, supply and a nominal shock. Specifically the contemporaneous responses of these variables are assigned signs that conform to economic theory. It is assumed that supply shocks increase relative output while reducing relative prices. The supply shock is assumed to be a domestic productivity shock, as given by an increase in the relative output variable. Demand shocks increase both relative output and relative 
prices while leading to an exchange rate appreciation. The demand shock, as a particular example, might arise due to a foreign output shock[3]. Nominal shocks increase both relative output and relative prices, but leads to an exchange rate depreciation. These sign-restrictions are contemporaneous and are summarised as:

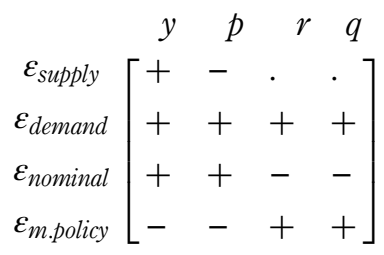

where $\varepsilon_{m}$. policy is a contractionary monerary policy shock. The TVP-VAR is then set-up as follows:

$$
Z_{t}=c_{t}+\sum_{l=1}^{L} \varphi_{l, t} Z_{t-l}+v_{t}
$$

where $Z_{t}=y_{t}, p_{t}, r_{t}, q_{t}(y=$ relative output growth, $p=$ relative price inflation, $r=$ interest rate differential and $q=$ exchange rate) and $L$ is the lag length. The parameters are assumed to have the following law of motion: $\hat{\varphi}_{l, t}=\hat{\varphi}_{l, t-1}+\omega_{t} . \omega_{t}$ is a vector of innovations. The covariance matrix is factored as:

$$
\operatorname{VAR}\left(v_{t}\right)=\Omega_{t}=A_{t}^{-1} H_{t}\left(A_{t}^{-1}\right)^{\prime}
$$

These time-varying matrices are defined as:

$$
H=\left[\begin{array}{llll}
h_{1, t} & 0 & 0 & 0 \\
0 & h_{2, t} & 0 & 0 \\
0 & 0 & h_{3, t} & 0 \\
0 & 0 & 0 & h_{4, t}
\end{array}\right] \text { and } A_{t}=\left[\begin{array}{llll}
1 & 0 & 0 & 0 \\
\alpha_{21, t} & 1 & 0 & 0 \\
\alpha_{31, t} & \alpha_{31, t} & 1 & 0 \\
\alpha_{41, t} & \alpha_{42, t} & \alpha_{43, t} & 1
\end{array}\right]
$$

The parameters in $H$ and $A$ evolve according to $\ln h_{t}=\ln h_{t-1}+\hat{v}_{t}$ and $\alpha_{t}=\alpha_{t-1}+\tau_{t}$. The vector of innovations is distributed as follows:

$$
\left[\begin{array}{c}
v_{t} \\
\omega_{t} \\
\tau_{t} \\
\hat{v}_{t}
\end{array}\right] \sim N(0, V) \text { with } V=\left[\begin{array}{llll}
\Omega_{t} & 0 & 0 & 0 \\
0 & Q & 0 & 0 \\
0 & 0 & S & 0 \\
0 & 0 & 0 & G
\end{array}\right] \text { and } G=\left[\begin{array}{llll}
\sigma_{1}^{2} & 0 & 0 & 0 \\
0 & \sigma_{2}^{2} & 0 & 0 \\
0 & 0 & \sigma_{3}^{2} & 0 \\
0 & 0 & 0 & \sigma_{4}^{2}
\end{array}\right]
$$

The presence of time variation allows us to model the unconditional and conditional volatility, as measured in standard deviations, at each point in time. The unconditional variance-covariance matrix of $Z_{t}$ is represented as:

$$
\int_{-\pi}^{\pi} \hat{f}_{t \mid T^{i u}(\omega) d \omega}
$$


$\hat{f}_{t \mid T^{i i}(\omega)}$ is the spectrum of the $i$ th endogenous variable at frequency $\omega$. The diagonal values of $\hat{f}_{t \mid T^{i i}(\omega)}$ are real valued and non-negative for all $\omega$ while the off-diagonal will be complex numbers (Hamilton, 1994). The spectral-density matrix is calculated as:

$$
\hat{f}_{t \mid T^{i}(\omega)}=\left(I_{4}-\hat{\varphi}_{t \mid T} e^{-i \omega}\right) \frac{\hat{\Omega}_{t \mid T}}{2 \pi}\left[\left(I_{4}-\hat{\varphi}_{t \mid T} e^{-i \omega}\right)^{-1}\right]^{\prime}
$$

We use similar priors as Mumtaz and Sunder-Plassmann (2013). The Gibbs-Sampler is used to draw from a lower dimensional conditional posterior. The first ten years serve as our training sample. This is done by estimating constant OLS parameters that serve as the priors in the TVP-VAR. $\hat{v}^{\text {ols }}$ is the OLS estimate of the covariance matrix estimated from the constant model. The conjugate prior for $Q$ is the Inverse Wishart $Q_{0} \sim I W\left(\bar{Q}_{0}, T_{0}\right)$ where the variance of $T_{0}$ equals 40 (this is a tight prior to avoid implausible time-varying behaviour). 40 is the degrees of freedom (ten years for the training sample). $\bar{Q}_{0}=0.0001(3.5)^{*}$ variance of the OLS estimates. The 0.0001 is the prior belief in the amount of variation. If this is too high then too much time variation is introduced. If the prior is too low it implies that we believe that fundamental shocks are not responsible for exchange rate variability. The prior for the off-diagonal elements in $A_{t}$ is $A_{t} \sim N\left(\hat{a}^{\text {ols }}, V\left(\hat{a}^{\text {ols }}\right)\right)$ where $\hat{a}^{\text {ols }}$ is the off-diagonal elements of $\hat{v}^{\text {ols }}$. G follows and inverse-gamma distribution $G \sim I G\left(10^{-4} / 2,1 / 2\right)$, while the blocks of $S$ follows an inverseWishart distribution: $S_{i, 0} \sim I W\left(\bar{S}_{i}, K_{i}\right)$ where $i$ indexes the blocks of $S . \bar{S}_{i}$ is calibrated using $\hat{a}^{\text {ols }}(0.001)$. In the Gibbs sampling we use 50,000 draws with a burn-in of 150,000.

\section{Results}

\section{Volatility}

The unconditional volatility of the exchange rate has increased since the inception of inflation targeting by the SARB in 2000 (see Figure 1). This is not surprising given that this is not the SARB's main objective function. The SARB has also limited its open market operations to influence the rand since 2000 .

Mumtaz and Sunder-Plassmann (2013) suggest that an increase in exchange rate volatility to output volatility indicates a disconnect between the exchange rate and fundamentals. While this seems to have happened in South Africa, the relative volatility difference is small and has been fairly stable since 2007 . This also seems to be the case for relative currency volatility to price volatility.

We further explore the relationship of the exchange rate with fundamentals in analysing how they are jointly influenced by cycles at various frequencies. The off-diagonal elements of the spectral-density matrix provide us with a summary of this relationship, which is called coherence $\left(\hat{c}_{i j}(\bar{\omega})\right)$. It measures the covariance between series at different frequencies, and the imaginary part of the off-diagonal elements of the spectral-density matrix $\left(\hat{q}_{i j}(\bar{\omega})\right)$, measures the possibility that series are at different phases in the cycle:

$$
\hat{h}_{i j}(\bar{\omega})=\frac{\left[\hat{c}_{i j}(\bar{\omega})\right]^{2}+\left[\hat{q}_{i j}(\bar{\omega})\right]^{2}}{\hat{f}^{i i}{ }_{t \mid T^{i}(\omega)}} \hat{f}_{t \mid T^{i}(\omega)}
$$

High values of $\hat{h}_{i j}(\bar{\omega})$ may reflect that series $i$ and $j$ share a common cycle at a particular frequency. Note that $<<\hat{h}_{i j}(\bar{\omega})<1$. As an example a high $\hat{h}_{i j}(\bar{\omega})$ for the exchange rate and interest rate differentials would imply that a relationship exists between them at various horizons. 

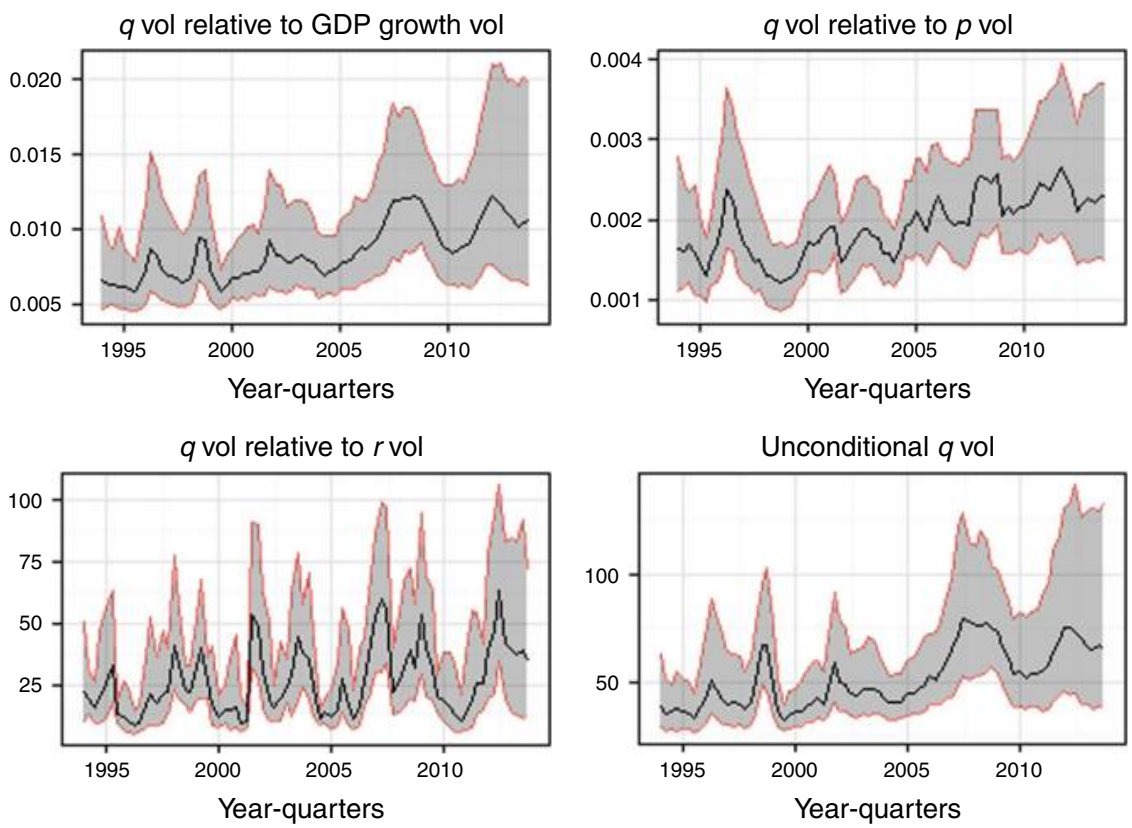

Figure 1. Conditional and unconditional exchange rate volatility (with standard errors)

Figures 2, 3 and 4 measure the level of coherence of the real exchange rate with price, output and interest rate differentials, respectively. The level of coherence between the exchange rate and price differentials at various horizons and over various business cycle frequencies (1, 2.5 and 5 years) has decreased over time. But, has increased since the $2008 / 2009$ financial crises. It points to importance of different regimes in explaining exchange rate movements.

The coherence estimate between the exchange rate and output, although not low, has decreased over a relatively long period. Again, signifying that at certain points in time the exchange rate is more influenced by other factors that are not structural (for a good indication of what these other factors might be see de De Bruyn et al., 2013). These results, however, are prone to regime shifts.

The coherence measure of the exchange rate and interest rate differentials are stable over time and over different business cycle frequencies. The highest measure of coherence is over cycles of 2.5 years - the measure is close to 1 . However, unlike the coherence measures for output and prices, the relationship between the exchange rate and interest rates continue to weaken post financial crisis. This suggests that the relationship between the exchange rate and fundamentals are mixed at best; there is a moderate association among relative prices and output differentials to the exchange rate, which changes over time and is possibly subject to economic cycles.

\section{Impulse responses}

The impulse responses are based on the sign-restrictions from Section 4. We present exchange rate responses to demand, supply and nominal shocks. The impulse responses are calculated by taking the forecast of a specific variable conditioned on a shock, minus the forecast of the model where the shock equals zero. The shocks are 

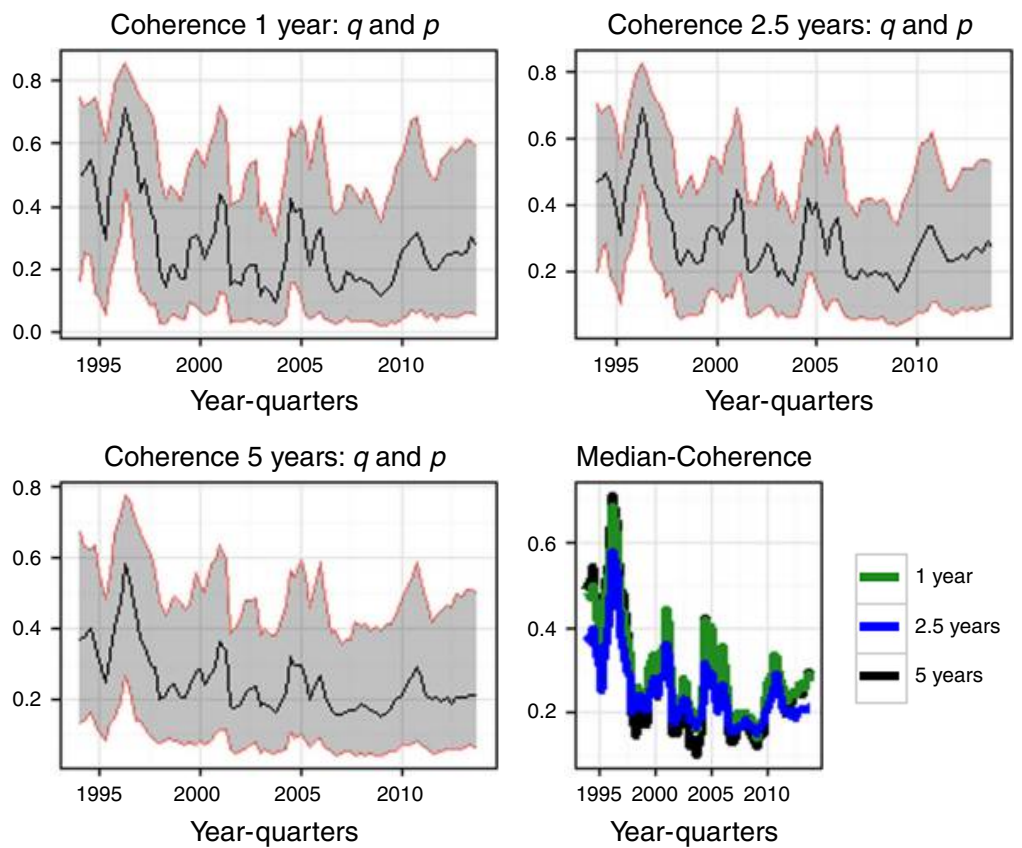

Figure 2. Coherence: exchange rate and relative prices
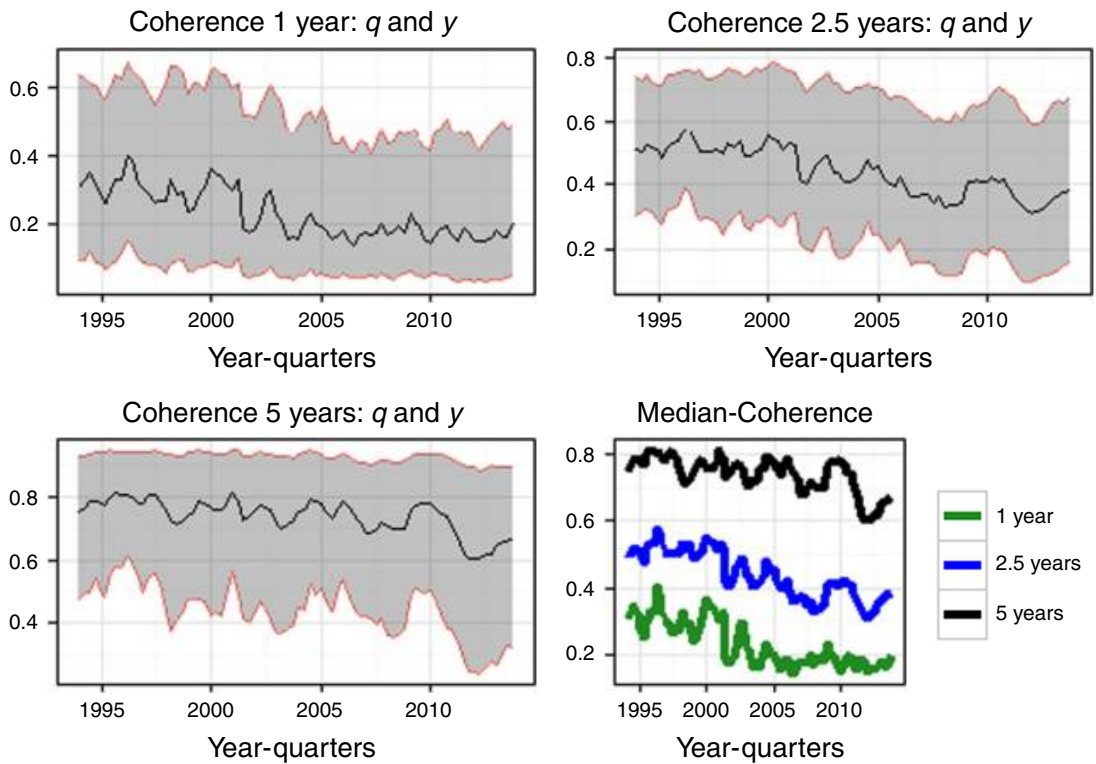

Figure 3. Coherence: exchange rate and relative output growth

normalised so that they increase contemporaneous output by one per cent at each point in time. Note that an increase in the exchange rate implies an appreciation. We divide the shocks into four time periods (1994Q1-1999Q4, 2000Q1-2004Q4, 2005Q1-2009Q4 and 2010Q1-2013Q4). 
Coherence 1 year: $q$ and $r$

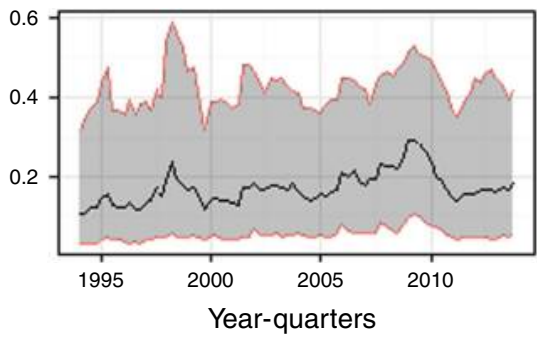

Coherence 5 years: $q$ and $r$

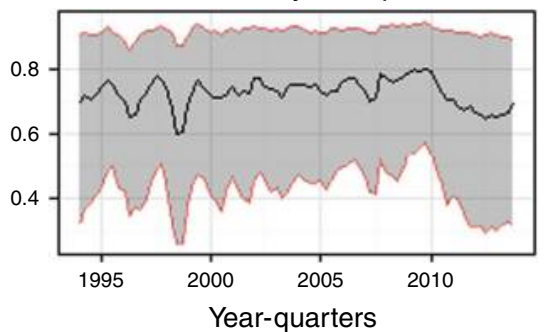

Coherence 2.5 years: $q$ and $r$
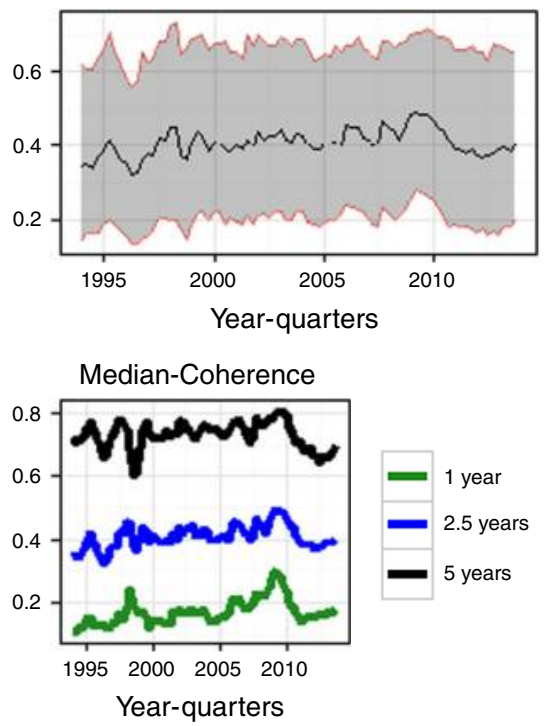

Figure 4. Coherence: exchange rate and nominal shocks

All three shocks have a permanent effect on the exchange. A demand shock leads to a currency appreciation over time. These results compare well to the coherence measures the impulse responses show that the effect of demand shocks on the exchange rate has decreased over time, but increased in the last period (2010Q1-2013Q4).

The exchange rate response to supply shocks has also changed over time. Our first period analysed shows that the exchange rate depreciated after a supply shock. In every subsequent period the exchange rate depreciated less. The final period shows that it appreciated. The difference in the exchange rate response over different periods could depend on many factors. Benigno and Thoenissen (2003) highlight that the lack of pricing power, domestic and abroad, by traded sectors, could reverse the BS effect. Furthermore, home-bias plays a crucial role - a larger weight on traded goods relative to non-traded goods in the consumption index reduces BS effects.

The response of the exchange rate to a monetary policy shock that raises output by 1 per cent also varies over time. The exchange rate has become increasingly responsive to interest rate differentials since inflation targeting. However, the responsiveness to the exchange rate to monetary policy shocks moderated during the 2010Q1-2013Q4 period. This emphasises the policy importance of understanding the limits of using interest rates when trying to influence the rand. One explanation for the decrease in responsiveness could be due to little variation in interest rate changes over this period (the repo changed four times and decreased by 150 basis points over this period compared to 12 announcements and a total movement of 10.5 percentage points during 2005Q1-2009Q4).

Mumtaz and Sunder-Plassmann (2013) argue that as exchange rate pass-through declines, the real exchange rate appreciates more in response to demand, supply and monetary policy shocks. This could explain the results obtained in Figure 5 - Jooste and Jhaveri (2014) show that exchange rate pass-through has decreased over time. 

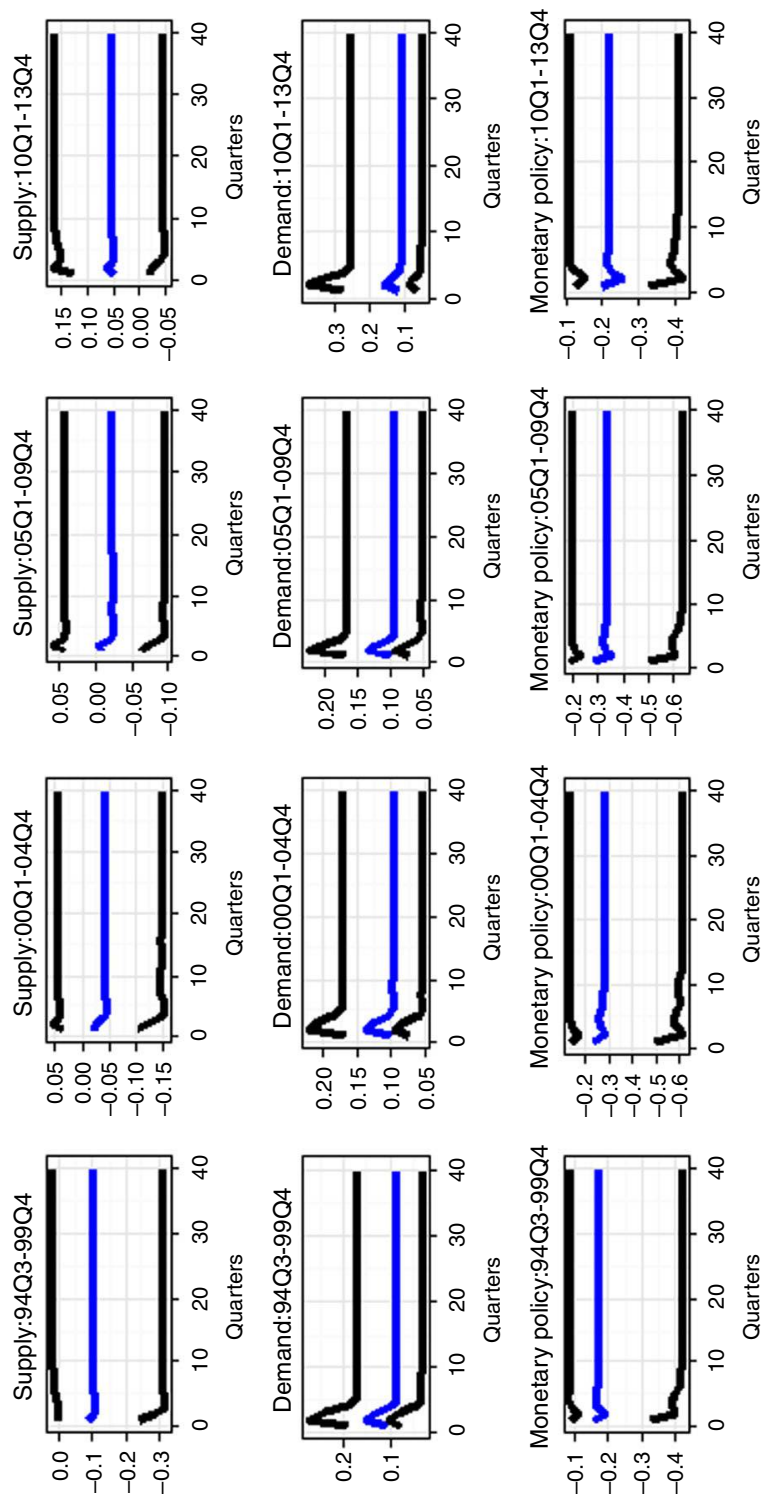

Figure 5. Exchange rate time-varying impulse response functions 


\section{Conclusion}

The relationship between the exchange rate and fundamental shocks has changed over time. Regime shifts play an important role in changing and describing the interactions between economic variables. We analyse this change by using a time-varying parameter VAR model. Our analyses rely on results obtained from volatility, joint dependence over business cycle frequencies and impulse responses over time. The relationship between the exchange rate and fundamental shocks has decreased since 1995 leading up to the 2008/2009 financial crisis. The time-varying dynamic responses of the exchange rate to fundamental shocks emphasise that regime shifts can change economic interactions and that policy should be cautious of these shifts.

The decoupling of the exchange rate to fundamental shocks over certain periods suggests that other factors influence the currency. Future research should try and pin down these non-fundamental shocks to complement the current knowledge of exchange rate behaviour. The non-constant exchange rate response to output, interest and price shocks hold important implications for policy - especially during periods central bank intervention is requested to influence the exchange rate.

It must be noted that this paper only shows that there has been some changes to the way exchange rate responds to certain shocks; it by no means identifies the causes of these changes. It would be both an important and interesting research path to quantify the exchange rate response to specific events - such as the effects of democratisation, monetary policy regimes, financial innovation and market interference such as liquidity injections by large economies. Further research could also test for possible timevarying cointegration - hence identifying the duration of equilibrium correction due to shocks over time.

\section{Notes}

1. This is not necessarily true if nominal shocks dominate exchange rate responses (Farrant and Peersman, 2006).

2. The data are stationary as given by $\mathrm{ADF}$ and $\mathrm{PP}$ tests. Results are available upon request.

3. The reader should note that there are many types of shocks that could give rise to demand and supply shocks. Remaining consistent with the theoretical model, we restrict these demand and supply shocks emanating only from a few variables.

\section{References}

Aron, J., Elbadawi, I. and Khan, B. (1997), "Determinants of the real exchange rate in SouthAfrica”, Working Paper 97-16, Centre for the study of African Economies, CSAE, Oxford University.

Benigno, G. and Thoenissen, C. (2003), "Equilibrium exchange rates and capital and supply side performance”, Economic Journal, Vol. 113 No. 486, pp. 103-124.

Chong, Y., Jorda, O. and Taylor, A. (2010), "The Harrod-Balassa-Samuelson hypothesis: real exchange rates and their long run equilibrium”, Working Paper No. 15868, National Bureau of Economic Research, available at: www.nber.org/papers/w15868 (accessed 5 July 2014).

Clarida, R. and Gali, J. (2004), "Sources of real exchange-rate fluctuations: how important are nominal shocks?", Carnegie-Rochester Conference Series on Public Policy, Vol. 41 No. 1, pp. $1-56$. 
De Bruyn, R., Gupta, R. and Stander, L. (2013), "Testing the monetary model for exchange rate determination in South Africa: evidence from 101 years of data", Contemporary Economics, Vol. 7 No. 1, pp. 19-32.

De Bruyn, R., Gupta, R. and Van Eyden, R. (2012), "Forecasting the rand-dollar and rand-pound exchange rates using dynamic model averaging", Mimeo, Department of Economics, University of Pretoria, Pretoria.

De Jager, S. (2012), "Modelling South Africa's real effective exchange rate: a VECM approach”, South African Reserve Bank Working Paper 12/02.

Du Plessis (2005), "Exogeneity in a recent exchange rate model: a response to MacDonald and Ricci”, South African Journal of Economics, Vol. 73 No. 4, pp. 741-746.

Égert, B. (2012), "Nominal and real exchange rate models in South Africa: how robust are they?", CESifo Working Paper No. 3853.

Farrant, K. and Peersman, G. (2006), "Is the exchange rate a shock absorber or a source of shocks? New empirical evidence”, Journal of Monev. Credit and Banking, Vol. 38 No. 4, pp. 939-961.

Fattouh, B., Mouratidis, K. and Harris, L. (2008), "South Africa's real exchange rate and the commodities boom: a Markov regime switching approach", CSAE Conference, Economic Development in Africa.

Faulkner, D. and Makrelov, K. (2008), "Determinants of the equilibrium exchange rate for South Africa's manufacturing sector and implication for competitiveness", African Econometric Society, Conference paper session IV.A, pp. 1-20.

Froot, K. and Rogoff, K. (1994), "Perspectives on PPP and Long-Run Real Exchange Rates", Working Paper No. 4952, NBER, Cambridge, MA.

Gupta, R., Makoena, M. and Van Eyden, R. (2009), “Testing for PPP using SADC real exchange rates", South African Iournal of Economics, Vol. 77 No. 3, pp. 351-362.

Hamilton, J.D. (1994), Time Series Analysis, Princeton University Press, Princeton, NJ.

Jooste, C. and Jhaveri, Y. (2014), "The determinants of time-varying exchange rate pass-through in South Africa", South African Journal of Economics, Vol. 82 No. 4, pp. 603-615.

Lacerde, M., Fedderke, J.W. and Haines, L.M. (2010), "Testing for purchasing power parity and uncovered interest parity in the presence of monetary and exchange rate regime shifts", South African Iournal of Economics, Vol. 78 No. 4, pp. 363-382.

MacDonald, R. and Ricci, L.A. (2004), "Estimation of the equilibrium real exchange rate for South Africa”, Vol. 72 No. 2, pp. 282-304.

Meese, R. and Rogoff, K. (1983), "Empirical models of the 1970's: do they fit out of sample?", Iournal of International Economics, Vol. 14 No. 1983, pp. 3-24.

Mumtaz, H. and Sunder-Plassmann, L. (2013), "Time-varying dynamics of the real exchange rate: an empirical analysis", Journal of Applied Economics, Vol. 8 No. 3, pp. 498-525.

Primiceri, G. (2005), "Time varying structural vector autoregressions and monetary policy", Review of Economic Studies, Vol. 72 No. 3, pp. 821-852.

Raputsoane, L. and Todani, K.R. (2008), "The exchange rate and macroeconomic fundamentals in South Africa", Presented at the African Econometric Society Conference 2008. University of Pretoria, Pretoria, 9-11 July.

Rogoff, K. (1996), “The purchasing power parity puzzle”, Journal of Economic Literature, Vol. 34 No. 2, pp. 647-668.

Sichei, M.M., Tewodros, G., Gebreselasie, A., Olusegun, A. and Akanbi (2005), “An econometric model of the rand-US dollar nominal exchange rate”, Working Paper No. 2005-14, University of Pretoria, Pretoria. 


\section{Further reading}

Dornbusch, R. (1980), "Exchange rate economics: where do we stand?", Brookings Paters on Economic Activity, Vol. 1980 No. 1, pp. 143-185.

Eichengreen, B. (2008), "The Real exchange rate and economic growth", Working Paper No. 4, Commission on Growth and Development, The International Bank for Reconstruction and Development/The World Bank On behalf of the Commission on Growth and Development, Washington, DC.

Frankel, J.A. (1979), "On the mark: a theory of floating exchange rates based on real interest differentials", American Economic Review, Vol. 69 No. 4, pp. 610-622.

Frankel, J.A. (2007), "On the Rand: determinants of the South African exchange rate", Working Paper No. 139i, Center for International Development, CID, Harvard, Cambridge, MA.

MacDonald, R. (1997), "What determines real exchange rates? The long and short of it", Working Paper No. 97/21, International Monetary Fund (IMF), Washington, DC.

MacDonald, R. and Nagayasu, J. (1998), "On the Japanese Yen-US dollar exchange rate: a structural econometric model based on real interest differentials", Iournal of the Iapanese and International Economies, Vol. 12 No. 1, pp. 75-102.

\section{Corresponding author}

Dr Rangan Gupta can be contacted at: rangan.gupta@up.ac.za 